\title{
Kompetencje tekstotwórcze absolwentów szkół ponadgimnazjalnych (na podstawie analizy rozprawek maturalnych)
}

\author{
Text-Creating Competence of the Students Graduating \\ from Upper Secondary Schools \\ (Conclusions Based on the Analysis of Essays in the Matura Exam)
}

Summary: Based on the analysis of 40 matura exam (secondary school-leaving exam) essays, the author of the article makes an attempt to determine how students graduating from high school cope with creating argumentative essays, especially when it comes to its composition and cohesion. While discussing the collected language material, particular attention was paid to the frame of the essays (introduction, conclusion), the method of elaborating the subject, and the content and graphic fragmentation of the writings. The observations made by the author allowed her to formulate conclusions about the text creating competence of the graduates taking matura exam: they use only part of the knowledge and skills acquired during the education. They find it difficult to draw up a piece of writing that is consistent with a specific genre pattern, in their essays there are many various types of lexical and stylistic as well as spelling and punctuation errors.

Key words: text-creating competence, high school graduates, essay, empirical research

O jakości wypowiedzi, także maturalnej, decydują m.in. umiejętności tekstotwórcze jej autora, poprawność językowa zredagowanego tekstu, a także funkcjonalny, ze względu na realizowany temat oraz formę, dobór środków językowych. Niestety, jak zauważają językoznawcy i dydaktycy ${ }^{1}$, coraz większa grupa

${ }^{1}$ Zob. D. Bartosiewicz: Sprawność tekstotwórcza jako integralny element oceny pisemnych prac maturalnych. W: Nowa matura a egzamin wstępny z języka polskiego. Red. R. Pawłowska. 
uczniów ma problemy z werbalizowaniem swoich myśli, odczuć, spostrzeżeń, z posługiwaniem się polszczyzną standardową. Młodzież z trudem radzi sobie również z budowaniem dłuższych, logicznie i kompozycyjnie uporządkowanych wypowiedzi, ma kłopoty z konsekwentnym przestrzeganiem wyznaczników wybranego wzorca gatunkowego, określeniem preferowanej strategii nadawczo-odbiorczej. Uczniom brakuje umiejętności tekstotwórczych ${ }^{2}$. W 2013 roku został opublikowany raport Diagnoza kompetencji gimnazjalistów. Język polski ${ }^{3}$. Czytamy w nim m.in.:

Umiejętności tekstotwórcze należą do jednych z najbardziej zaniedbanych w świetle prowadzonych badań. Opinia ta dotyczy nie tylko samych wstępów i zakończeń, ale także logiki prowadzenia wywodu oraz tworzenia spójności wewnątrz- i międzyakapitowej. Choć najczęściej uczniowie

Gdańsk 2001, s. 62-73; D. Krzyżyk: Wyznaczniki spójności tekstu w pracach pisemnych maturzystów. „Biuletyn maturalny OKE w Jaworznie: Przygotowanie ucznia do egzaminu maturalnego z języka polskiego". Cz. II. Jaworzno 2007, s. 43-52; Eadem: Umiejętności tekstotwórcze i językowe uczniów w pisemnych pracach maturalnych. W: Ksztatcenie językowe w dobie kultury masowej polisensorycznej. Red. U. Kopeć, Z. Sibiga. Rzeszów 2010, s. 149-163; K. Ożóg: Polszczyzna przełomu XX i XXI wieku. Wybrane zagadnienia. Rzeszów 2001; E. Polański: Typy uchybień uczniów w organizacji tekstu wypracowań. W: Polonistyka zintegrowana. Red. K. Ożóg, J. Pasterska. Rzeszów 2000; A. Rypel: Gimnazjaliści w epoce wtórnej oralności. Analiza wybranych wypowiedzi pisemnych. „Polonistyka. Innowacje” 2015, nr 1, s. 37-53; H. Synowiec: Język polski w szkole. W: Polszczyzna 2000. Orędzie o stanie języka na przetomie tysiącleci. Red. W. Pisarek. Kraków 1999, s. 115-129; H. Synowiec: O sytuacji języka ojczystego w zreformowanej szkole. W: Kompetencje nauczyciela polonisty we współczesnej szkole. Red. E. Bańkowska, A. Mikołajczuk. Warszawa 2006, s. 125-135; H. Synowiec: Stan polszczyzny uczniów na tle przemian kulturowych i cywilizacyjnych. W: Język polski jako narzędzie komunikacji we wspótczesnym świecie. Red. J. Mazur, M. Rzeszutko-Iwan. Lublin 2007, s. 105-114; A. Tabisz: Kompetencja tekstotwórcza uczniów na przykładzie rozprawki. Opole 2006; A. Wileczek: „Zrobić” tekst. O kompetencji tekstotwórczej gimnazjalistów. „Postscriptum Polonistyczne” 2015, nr 2, s. 167-184.

${ }^{2}$ Przyjmuję, że kompetencja tekstotwórcza ,przejawia się jako umiejętność tworzenia tekstu spójnego, zorganizowanego, stanowiącego informacyjną całość, stosownego do sytuacji, realizującego określony wzorzec gatunkowy”. E. Now ak: Stworzyć tekst. Uczniowska kompetencja tekstotwórcza w edukacji polonistycznej. Kraków 2014, s. 124. Jak zauważa Jolanta Nocoń: ,,[...] rozwój umiejętności tekstotwórczych jest skorelowany z rozwojem innych kompetencji i to nie tylko o charakterze językowo-komunikacyjnym". Na kompetencję tekstotwórczą składają się zatem: sprawność językowa (zdolność do tworzenia wypowiedzi poprawnych gramatycznie i językowo), sprawność komunikacyjna (świadome konstruowanie strategii nadawczej), świadomość językowa (wiedza o tym, co chcemy powiedzieć, co osiągnąć poprzez konkretny akt komunikacyjny, oraz jak to uczynić), a także świadomość kulturowa (jak mówić w kontekście kultury własnej i obcej). Zob. J. Nocoń: Rozwijanie i doskonalenie kompetencji tekstotwórczych w pespektywie lingwodydaktycznej. W: „Acta Universitatis Wratislaviensis. Kształcenie Językowe”. Red. K. Bakuła. Wrocław 2012, s. 28; E. Nowak: Stworzyć tekst..., s. 128.

${ }^{3}$ Diagnoza kompetencji gimnazjalistów. Język polski. Warszawa 2013. Raport opracowali pracownicy Instytutu Badań Edukacyjnych. 
mają opanowane typowe dla rozprawki formuly, np. „Moim pierwszym argumentem będzie...”, „Po pierwsze, po drugie”, „Kolejnym argumentem”, to jednak mają one charakter jedynie „ozdobny”, nie pełnią funkcji spajającej ${ }^{4}$.

W artykule na podstawie prowadzonych badań podejmuję próbę oceny kompetencji tekstotwórczej uczniów kończących edukację w liceum bądź w technikum. Na podstawie analizy ich maturalnych wypracowań chcę ustalić, jaki jest poziom umiejętności absolwentów szkół ponadgimnazjalnych, czy są one wyższe od umiejętności gimnazjalistów. $\mathrm{W}$ trakcie prowadzonych przeze mnie badań interesowało mnie, w jakim stopniu maturzyści potrafią wykorzystać zdobyte na wszystkich etapach edukacyjnych wiadomości i umiejętności do tworzenia prac realizujących określony wzorzec gatunkowy, poprawnych stylowo i językowo, także ortograficznie i interpunkcyjnie, spójnych pod względem logicznym, składniowym i znaczeniowym, w sposób celowy zachowujących wewnętrzny porządek, mających zaplanowaną i przemyślaną kompozycję, a ponadto realizujących temat i bezpośrednio odnoszących się do tekstu (materiału źródłowego) zamieszczonego $\mathrm{w}$ arkuszu egzaminacyjnym ${ }^{5}$.

Analizie poddałam 40 autentycznych wypracowań ${ }^{6}$. Uczniowie, którzy podjęli się napisania rozprawki, realizowali temat: Wolna wola człowieka czy sity od niego niezależne - co przede wszystkim decyduje o ludzkim losie? Rozważ problem i uzasadnij swoje zdanie, odwotujac się do podanego fragmentu Lalki, całego utworu Bolesława Prusa oraz innego tekstu kultury. Twoja praca powinna liczyć co najmniej 250 stów ${ }^{7}$.

${ }^{4}$ Ibidem, s. 34.

${ }^{5}$ Por. J. Nocoń: Rozwijanie i doskonalenie kompetencji tekstotwórczych..., s. 28.

${ }^{6}$ Prace zostały udostępnione przez Okręgową Komisję Egzaminacyjną w Jaworznie w roku 2016 (prace uczniowie pisali w sesji letniej w 2015 roku). Spośród analizowanych wypracowań 20 opracowała mgr Anna Sikora, 20 - autorka artykułu. Formułując wnioski i uogólnienia, autorka odwoływała się także do swoich notatek poczynionych w trakcie sprawdzania prac maturalnych. Badając kompetencję tekstotwórczą, analizowała strukturę uczniowskich wypracowań (budowę tzw. ramy kompozycyjnej i części argumentacyjnej, rozczłonkowanie treściowe i graficzne) oraz stopień zachowania spójności lokalnej, a także poszczególne cechy stylistyczne i językowe maturalnych tekstów. Sprawdzała zatem, czy teksty te są pewną informacyjną całością, która realizuje określony wzorzec gatunkowy.

${ }^{7} \mathrm{~W}$ trakcie prowadzonych badań analizie poddano także inne wypowiedzi maturalne $\mathrm{z}$ roku 2015: 40 wypracowań z poziomu podstawowego napisanych na temat 2: Zinterpretuj podany utwór. Postaw teze interpretacyjna i ja uzasadnij. Twoja praca powinna liczyć co najmniej 250 stów; 40 wypracowań maturalnych z poziomu rozszerzonego na temat 1: Określ, jaki problem podejmuje Umberto Eco w podanym tekście. Zajmij stanowisko wobec rozwiazania przyjętego przez autora, odwolujac się do tego tekstu oraz innych tekstów kultury. Twoja praca powinna liczyć co najmniej 300 słów; 40 wypracowań maturalnych z poziomu rozszerzonego, które zostały napisane na temat 2: Dokonaj interpretacji porównawczej podanych tekstów. Twoja praca powinna liczyć co najmniej 300 stów. Wyniki pozostałych analiz zostaną omówione w kolejnych publikacjach. 
Analizowane wypracowania maturalne pochodziły z różnych przedziałów staninowych $^{8}$ — po sześć prac z przedziału 1 i 9 oraz po cztery prace z przedziałów 2-8. Prace zostały wybrane w sposób losowy przez osoby do tego upoważnione i pochodziły z różnych szkół oraz miejscowości. Wypracowania zostały wcześniej również odpowiednio przygotowane — w udostępnionych kopiach nie pojawiły się informacje o płci autora pracy oraz utajono numery PESEL. Kopie nie zawierały także komentarzy osób sprawdzających wypracowania maturalne.

Kompozycja uczniowskich wypowiedzi maturalnych — za Michałem Kuziakiem i Sławomirem Rzepczyńskim — może zostać porównana do odwiedzin w czyimś mieszkaniu:

Autor pracy to gospodarz mieszkania, jej czytelnik to odwiedzający gość. Najpierw nasz gość wejdzie do przedpokoju, w którym wstępnie rozpozna układ mieszkania [...]. Następnie gospodarz zaprowadzi gościa do poszczególnych pomieszczeń (niekoniecznie wszystkich, nie wszystko musimy pokazywać, to gospodarz decyduje, jakie pomieszczenia zaprezentować) [...]. Wreszcie odchodzącego gościa zaprowadzimy do przedpokoju, by mógł opuścić nasze mieszkanie (nie wyrzucimy go przecież przez okno ani nie przeniknie przez ścianę) [...]. Pisząc, zapraszamy niejako czytelnika do zwiedzenia mieszkania naszych myśli ${ }^{9}$.

Przywołana metafora w doskonały sposób określa specyfikę gatunków wypowiedzi maturalnych. Dzięki takiemu obrazowemu przedstawieniu bez problemów możemy wskazać na elementy, które w kompozycji wypracowań są niezbędne. Przede wszystkim zauważyć można, że wypracowania maturalne powinny składać się z trzech podstawowych części: wstępu (przedpokój), rozwinięcia (pomieszczenia w głębi mieszkania) i zakończenia (przedpokój; widziany jednak z innej perspektywy niż na początku wizyty). Pomieszczenia mają być rozumiane jako poszczególne argumenty, które świadomie zostaną wybrane przez autora pracy i przedstawione w określonej kolejności. Istotne jest jednak to, by miały one charakter strategiczny - czytelnika (gościa) nie będą bowiem interesowały argumenty słabe, które zostały wybrane w przypadkowy sposób i nie są tym samym dla niego przekonujące. Wizyta w „mieszkaniu myśli” ma ponadto przebiegać w sposób logiczny i spójny — autor pracy musi za-

${ }^{8}$ Przedział staninowy to skala dydaktyczna. Wskazuje na pozycję, którą zajmuje wynik osiągnięty przez ucznia na tle wszystkich badanych wyników. Wyróżnia się 9 podziałów wyników: 1 (najniższy; poniżej 4\%), 2 (bardzo niski; 4-10\%), 3 (niski; 11-22\%), 4 (niżej średni; 23-39\%), 5 (średni 40-59\%), 6 (wyżej średni; 60-76\%), 7 (wysoki; 77—88\%), 8 (bardzo wysoki 89—95\%), 9 (najwyższy; powyżej 95\%). Zob. Skale staninowe. W: Serwis Okręgowej Komisji w Poznaniu. http://uczniowie.oke.poznan.pl [data dostępu: 2.06.2016].

9 M. Kuziak, S. Rzepczyński: Jak pisać?. Warszawa 2008, s. 165. 
tem pamiętać, że tworzony przez niego tekst jest pewnym całościowym i zhierarchizowanym komunikatem. Kształtując strukturę tekstu własnego poprzez określoną organizację trzech poziomów realizacji językowej, nadawca powinien także dążyć do osiągnięcia zamierzonego celu komunikacyjnego, zrealizowania założonej intencji ${ }^{10}$.

Należy jednak zdawać sobie sprawę, że kompozycja danego tekstu zależy od konkretnego gatunku wypowiedzi, w którym jest on realizowany. Inna zatem będzie kompozycja wypowiedzi argumentacyjnej, a inna np. artykułu prasowego. Ze względu na podjęty temat istotna jest kompozycja wypowiedzi maturalnych, która

oceniana jest ze względu na funkcjonalność segmentacji i uporządkowanie tekstu zgodnie $\mathrm{z}$ wybranym przez ucznia gatunkiem wypowiedzi ${ }^{11}$.

Rozprawka, będąca wypowiedzią argumentacyjną, ma charakterystyczną dla siebie kompozycję — składa się z trzech podstawowych części: wstępu, rozwinięcia i zakończenia. Zatarcie punktów granicznych tekstu — wstępu i zakończenia - może spowodować rozchwianie jego struktury ${ }^{12}$. Początek i koniec danej wypowiedzi są więc bardzo ważne dla całościowego odbioru komunikatu. Dlatego też przyjrzę się najpierw wstępom i zakończeniom redagowanym przez maturzystów. Następnie analizie poddam najistotniejszą część rozprawki - rozwinięcie. To bowiem w zasadniczej części pracy maturzyści powinni przekonać odbiorcę do przyjętej przez siebie tezy. Podczas analizy rozwinięć uczniowskich rozprawek szczególną uwagę zwrócę na dobór argumentów oraz na sposoby realizacji tematu wypracowania. Ostatnim elementem, który zostanie przeze mnie zbadany, będzie graficzne i treściowe rozczłonkowanie tekstu.

${ }^{10}$ L. Tymiakin: Kompozycja uczniowskiego tekstu argumentacyjnego. „Annales Universitatis Mariae Curie-Skłodowska. Sectio FF, Philologiae”. Vol. XXII. Red. M. Woźniakiewicz-Dziadosz. Lublin 2004, s. 147-159.

${ }^{11}$ Informator o egzaminie maturalnym z języka polskiego od roku szkolnego 2014/2015. Warszawa 2013, s. 144.

${ }_{12}$ Wcześniej prowadzone przeze mnie badania wykazały, że absolwenci szkół ponadgimnazjalnych popełniają szereg błędów i uchybień w zakresie spójności tekstu, zwłaszcza w wypowiedziach zrygoryzowanych (np. rozprawkach). Odnotowałam m.in.: częsty „brak proporcji między poszczególnymi segmentami pracy — uczniowie zazwyczaj wiele uwagi poświęcają wstępowi (nierzadko włączają do niego argumentację przynależną rozwinięciu lub piszą wszystko, co wiedzą na temat epoki, autora, utworu literackiego; wstępy bardzo często są niefunkcjonalne, nie są podporządkowane realizacji tematu); bywa, że maturzyści redagują wypowiedzi ułomne, pozbawione zazwyczaj zakończenia lub zwieńczone jedno-, dwuzdaniowym podsumowaniem; brak bezpośredniego związku treściowego między wstępem a rozwinięciem i zakończeniem (każdy człon może wówczas funkcjonować oddzielnie — pojawić się w innym wypracowaniu; treści zawarte w zakończeniu nie wynikają z wcześniejszej analizy i interpretacji, są luźno związane z tematem, mają charakter impresyjny bądź są powtórzeniem tezy czy też nieudolnie przekształconą hipotezą)". Zob. D. Krzyżyk: Wyznaczniki spójności tekstu..., s. 44. 


\section{Rama rozprawek maturalnych}

Nie ulega wątpliwości, że dobry wstęp rozprawki musi zawierać stanowisko autora, jakie zajmuje on wobec problemu, który został ujęty w temacie wypracowania. To podstawowy element, od którego rozpoczyna się myślenie autora danej pracy o jej kształcie, w tym o kolejnych argumentach i wynikających z ich prezentacji wnioskach. Wykres 1 przedstawia, w jaki sposób maturzyści formułowali swoje stanowisko wobec problemu wskazanego w temacie wypracowania, jakie przyjęli strategie.

\section{Sposoby formulowania stanowiska $\mathrm{w}$ rozprawce}

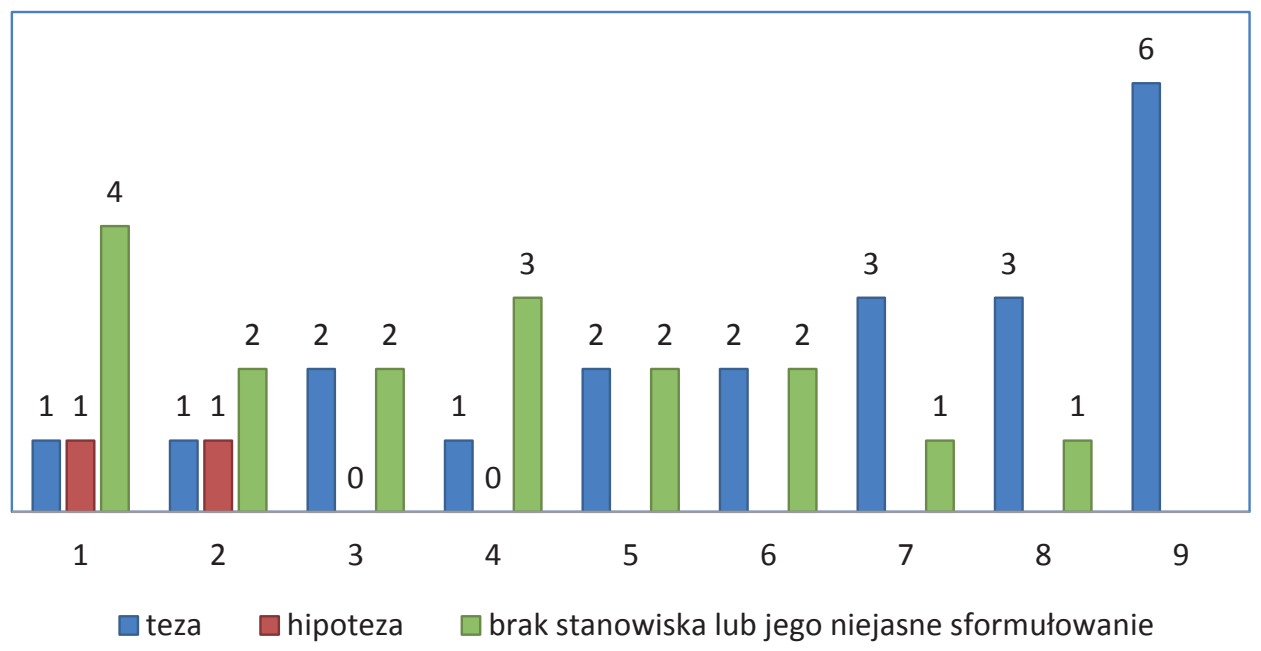

Źródło: Opracowanie własne.

Jak pisze Anna Tabisz, można wyróżnić trzy podstawowe strategie formułowania stanowiska przez autora tekstu. Pierwsza z nich zakłada, że na początku zostanie postawiona teza, która w dalszej części pracy popierana będzie argumentami udowadniającymi jej słuszność. W zakończeniu zaś ma miejsce jej potwierdzenie. Drugi sposób polega na postawieniu tezy wątpliwej. W takim wypadku w rozwinięciu pojawiają się zarówno argumenty, jak i kontrargumenty. Charakterystyczne dla tego typu sformułowania problemu jest to, że o postawionej w zakończeniu tezie decyduje przewaga argumentów typu ,za”. Ostatnią z możliwości jest rozpoczęcie wypracowania od hipotezy. W rozwinięciu autor pracy poszukuje rozwiązania problemu, a dopiero w zakończeniu formułuje tezę ${ }^{13}$.

\footnotetext{
${ }^{13}$ Zob. A. Tabisz: Kompetencja tekstotwórcza uczniów..., s. 68-69.
} 
Na podstawie danych z wykresu 1 można zauważyć, że 21 analizowanych rozprawek rozpoczynało się od zaprezentowania tezy, co jest z pewnością najpowszechniejszą praktyką osób piszących rozprawkę. Tylko dwóch maturzystów zdecydowało się na postawienie hipotezy. Niepokojące jest jednak to, że aż 17 prac nie zawierało ani tezy, ani hipotezy, i to niezależnie od przedziału staninowego (tylko prace z 9 przedziału były kompletne), np.:

Niektórzy zadają sobie ciągle nurtujące pytanie — przypadek? Czy ktoś z góry zaplanował nam ścieżkę życia. Zdań jest tyle ile ludzi na świecie, ja na szczęście muszę przybliżyć, czy człowiek sam kieruje swoim losem czy też nie ma na to żadnego wpływu (IPP1/2) ${ }^{14}$.

Ludzkie życie jest usłane niespodziankami. Jedne są przyjemne, inne wcale nas nie zachwycają. Dlatego niektórzy nie lubią niespodzianek i zaskoczeń (IPP1/5).

Nigdy nie wiemy, co nas może w życiu spotkać, czy coś dobrego, czy coś złego. Nie wiemy też, kto o tym decyduje, czy my sami, czy nasze otocznie, czy jakieś siły wyższe (IPP 4/6).

Jak widać, autorzy zacytowanych wstępów nie sformułowali stanowiska, jakie zajmować będą wobec problemu podanego w poleceniu. Zaproponowane wstępy są także bardzo ogólne - nie dowiadujemy się bowiem, co dokładnie stanowi przedmiot rozważań ani jaki będzie tok myślowy autora danej pracy. Przywołane wprowadzenia są ponadto niefunkcjonalne - wynika to zarówno z ich powierzchniowości, jak i schematyczności.

Za niefortunne (niefunkcjonalne) uznawane są jednak nie tylko krótkie wstępy, por. przykłady:

Blaise Pascal powiedział, że „człowiek jest trzciną, najwątlejszą w przyrodzie, ale trzciną myślącą". Na przestrzeni epok człowiek i poglądy na temat człowieka ewoluowały. W starożytności człowiek był niczym kukiełka w porównaniu do potęgi bogów, determinujących jego losy. Średniowiecze to była epoka Boga, surowego, karzącego za błędy. Człowiek żył w ciągłym strachu — zarówno o sprawy ziemskie, jak i zbawienie wieczne. Pierwszą epoką, która dostrzegła człowieka, odkryła jego potrzeby, pragnienia, namiętności i zdolności, było odrodzenie. Człowiek stał się autonomiczną jednostką, wyzbył się strachu i zaczął walczyć o własne szczęście (IPP2/9).

${ }^{14}$ Cytowane prace oznaczam w następujący sposób: IPP1/2: PP — poziom podstawowy; 1 numer analizowanej pracy z danego przedziału staninowego; 2 - przedział staninowy. W każdej $\mathrm{z}$ cytowanych przeze mnie prac zachowuję oryginalną pisownię. 
Wolną wolę dał nam Bóg. Możemy robić wszystko bez ograniczenia, wybierać, zastanawiać się, podejmować decyzje, zmieniać je, wszystko jest możliwe (IPP4/8).

Mimo że początek rozprawki IPP2/9 jest bardziej rozbudowany od cytowanych wcześniej wstępów, nie możemy jednak mówić o tym, by był on napisany poprawnie. Odbiorca może mieć bowiem wątpliwości co do przedmiotu rozważań autora - czy będzie pisał o ewolucji poglądów na temat człowieka, czy o tym, kiedy człowiek stał się autonomiczną jednostką. Choć wstęp ten jest bardzo rozwinięty, autor pracy nie stawia w nim także ani tezy, ani hipotezy, a więc pomija podstawowe elementy, które powinny zostać włączone do wstępu rozprawki.

By napisać dobry wstęp, nie wystarczy jednak sformułować tezę lub hipotezę. Należy pamiętać również o tym, by był on merytorycznie poprawny, wprowadzał w podejmowany przez autora problem i sygnalizował tok jego myślenia. Dobrze zbudowany wstęp, który stanowi pewną inicjalną formułę, powinien także zachęcić odbiorcę tekstu do dalszej lektury pracy. Tylko taki rodzaj wstępu może zostać uznany za pogłębiony.

Na podstawie danych ujętych na wykresie 2 widać, że tylko nieliczni maturzyści potrafili zbudować dobry wstęp, spełniający wszystkie zasygnalizowane warunki.

\section{Budowa wstępów — rozprawka}

Wykres 2

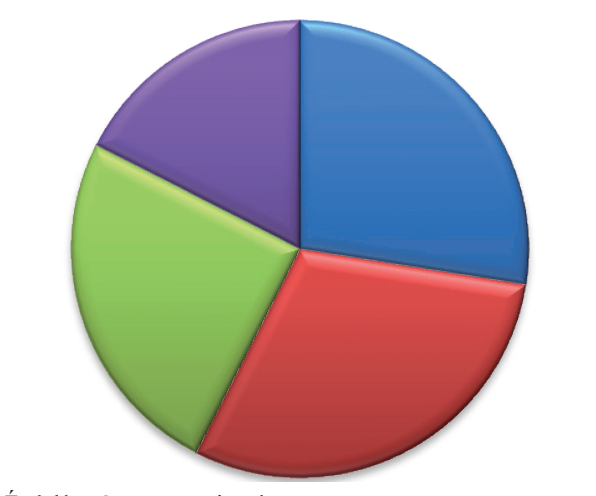

অwstęp pogłębiony lub częściowo pogłębiony

•wstęp niepogłębiony, ogólnikowy

⿶wstęp dysfunkcyjny

•brak wstępu

Źródło: Opracowanie własne.

Tylko 27\% zdających napisało wstępy, które można by uznać za pogłębione. Niestety, nie zawierały one wszystkich cech dobrego wstępu, dlatego też zostały ulokowane na powyższym diagramie łącznie ze wstępami częściowo pogłębionymi. Autorami tych prac byli maturzyści, których wyniki (zdobyte za wypracowanie punkty) mieszczą się w 8 i 9 przedziale staninowym, por.: 
Ludzie oraz to, co z nimi związane to główny temat poruszany od wieków w literaturze. Pisarze skupiają się na człowieku, jego psychice, życiu. Przedstawiają go w różnoraki sposób - jako silnego bądź słabego, dobrego lub złego i zepsutego. Jednak co, tak naprawdę, decyduje o ludzkim losie? Czy ze względu na to, że posiada wolną wolę, może kierować swoim życiem i być pewnym tego, co zaplanuje, wybierze? Według mnie, o losie człowieka decydują siły od niego niezależne (IPP1/8).

Człowiek, jako istota rozumna, obdarzona wolną wolą, ma oczywiście zdolność podejmowania własnych decyzji i działań. W gruncie rzeczy nie wie jednak nigdy, dokąd tak naprawdę zmierza, nawet jeśli „podąża własną drogą". Moim zdaniem, koniec tej drogi jest wyznaczany nie przez samego wędrowca, ale przez siłę niezależną od niego, wyższą — jakimkolwiek mianem by tej siły nie określić (IPP1/9).

Życie każdego człowieka jest niepowtarzalne, dlatego stanowi od wieków przedmiot rozważań filozofów. Kwestia, czy człowiek ma wpływ na własny los, to jeden z głównych problemów egzystencjalnych. Świadczą o tym dążenia znanych myślicieli, a w szczególności św. Augustyna, do podporządkowania świata bytowi idealnemu, który nadałby sens dziejom ludzkości. Dziś zatem możemy wysnuć wniosek, że los jest niezależny od wolnej woli człowieka, także światem kieruje wyższa siła (IPP1/7).

Pomijając poprawność językowo-stylistyczną zacytowanych fragmentów, należy zwrócić uwagę na fakt, że ich autorzy spełnili niektóre warunki, które decydują o tym, że dany wstęp określany jest jako dobry. Przede wszystkim czytelnik został wprowadzony w podjęty temat, czyli autorzy prac nakreślili problematykę, której będzie poświęcone wypracowanie. W poprawny sposób sformułowane tezy zostały wprowadzone w odpowiednim miejscu. Częściowo zasygnalizowany został także tok myślowy autorów prac. Zacytowanym wstępom można jednak zarzucić to, że nie informują one odbiorcy o wiedzy przedmiotowej czy ogólnej ich autorów. Wyjątek stanowi praca IPP1/7, w której autor, choć w ograniczonym zakresie, powołuje się na św. Augustyna oraz na filozofię egzystencjalną. Ocenie nie zostanie poddana jednak efektowność przytoczonych wstępów, gdyż to, czy zachęcają one odbiorcę do dalszej lektury, jest już jego subiektywnym odczuciem.

Większość napisanych przez maturzystów wstępów została zredagowana w taki sposób, że zostały one uznane za zbyt ogólnikowe - wymagają bowiem doprecyzowania:

Często słyszymy, że człowiek posiada wolną wole. Być może tak jest, ale czy napewno jeśli chodzi o uczucia? (IPP3/1). 
Każdy człowiek posiada własną wolę, ma zdolność decydowania o swej przyszłości. Jednak zazwyczaj o ludzkim losie decydują zdarzenia niezależne od człowieka (IPP1/3).

Człowiek jako pojedyńcza jednostka nie jest w stanie wszystkiego przewidzieć i mieć na wszystko wpływ. Lecz ciężką pracą może poprawić każdą sytuację, może wszystko zmienić (IPP2/3).

Jak widać, wprowadzenia te są bardzo krótkie, ograniczają się zaledwie do dwóch zdań. W każdym ze wstępów (w pierwszym zdaniu) autorzy sygnalizują problem, który będzie poruszany w rozprawce. Niestety, nie rozwinęli tych myśli i już w następnym zdaniu zaprezentowali stanowisko. Nie można także mówić o przedstawieniu toku myślowego autora, gdyż wstępy te są mało konkretne.

W 25\% analizowanych prac odnotowałam wstępy dysfunkcyjne, czyli takie, które nie spełniały swojej funkcji — nie wprowadzały w problem i nie zawierały stanowiska autora. Takie początki cechował ponadto schematyzm, np.:

„Wolna wola człowieka czy siły od niego niezależne?”. W mojej pracy chciałabym rozważyć ten problem, oraz uzasadnić swoje zdanie na ten temat (IPP1/4).

W mojej poniższej pracy będę rozwiązywała problem, który został przedstawiony w temacie oraz w poniższym tekście utworu (IPP2/1).

Analizując wstępy napisane przez maturzystów, należy także zwrócić uwagę na różne sposoby rozpoczynania przez nich rozprawek (por. wykres 3).

Sposoby rozpoczynania rozprawek

Wykres 3

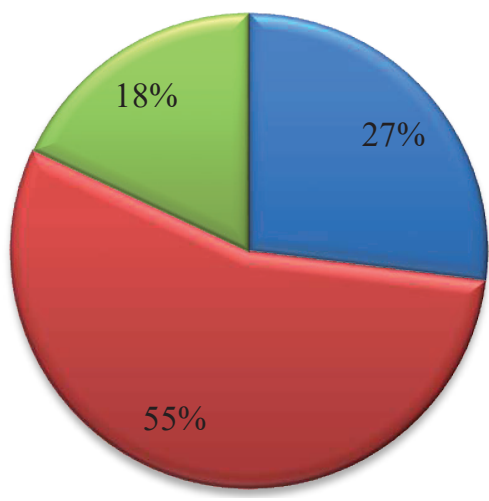

๑początki ściśle związane z tematem zadania - przywołanie tematu i refleksje wokół pojęć w nim zawartych

๑ogólne refleksje - początki mają postać zdań twierdzących i/lub pytających 
Maturzyści najczęściej rozpoczynali swoje wstępy od zdań twierdzących lub pytających, które stanowiły punkt wyjścia do dalszych, już bardziej pogłębionych, rozważań, np.:

Każdy człowiek jest podległy losowi. Na to jaki jest nam przypisany składa się wiele czynników, na które mimo woli człowiek nie ma wpływu. Los jest panem naszego życia [...] (IPP1/6).

Często słyszymy, że człowiek posiada wolną wolę. Być może tak jest, ale czy na pewno jeśli chodzi o uczucia? (IPP1/3).

Każdy człowiek staje w swoim życiu przed różnymi wyborami. Czy jednak o swoich losach decyduje on sam czy też ma na to wpływ los? (IPP3/8).

Co wpływa na ludzkie życie, co decyduje o jego statecznym kształcie? My sami? Ślepy los? A może jeszcze inne czynniki? (IPP4/7).

Takie lub podobnie zbudowane wstępy są w 55\% analizowanych prac.

Innym sposobem rozpoczynania rozprawek, który zastosowało $27 \%$ maturzystów, jest nawiązywanie w zdaniach inicjalnych do tematu wypracowania. Najczęściej przywoływany jest $\mathrm{w}$ nich cytat, który pojawił się w treści zadania, np.:

„Wolna wola człowieka czy siły od niego niezależne?”. W mojej pracy chciałabym rozważyć ten problem, oraz uzasadnić moje zdanie na ten temat (IPP1/4).

„Wolna wola człowieka czy siły od niego niezależne — co przede wszystkim decyduje o ludzkim losie?". Wbrew pozorom wcale to nie jest łatwe, proste i mające jednoznaczną odpowiedź pytanie [...] (IPP2/5).

„Wolna wola człowieka czy siły od niego niezależne?”. Na to pytanie będę szukać odpowiedzi w mojej pracy. Jednak już na wstępie mogę stwierdzić, że decydujące znacznie ma wolna wola (IPP4/7).

Żaden z maturzystów nie zdecydował się na sparafrazowanie przywołanego w poleceniu cytatu. W 18\% wypracowań nie ma wstępów.

Zdecydowanie większą trudność sprawiło maturzystom zbudowanie poprawnych, uzasadnionych wcześniejszymi dociekaniami zakończeń. W żadnej z prac nie pojawił się bowiem taki koniec rozprawki, który byłby pogłębionym podsumowaniem rozważań, tzn. miał charakter refleksyjny, odwoływał się do przedstawionych argumentów, w tym do tekstów kultury, a ponadto zawierał powtórzoną tezę lub tezę dopiero sformułowaną, której nie było we wstępie, gdyż autor pracy rozpoczynał swoje rozważania od postawienia hipotezy lub 
tezy wątpliwej. W analizowanych pracach dominowały zakończenia ogólnikowe, luźno nawiązujące do rozwinięcia pracy. W ogóle w analizowanym materiale nie było prac z zakończeniami pełnymi, pogłębionymi, zbierającymi wcześniejsze spostrzeżenia (por. wykres 4).

\section{Budowa zakończeń — rozprawka}

Wykres 4

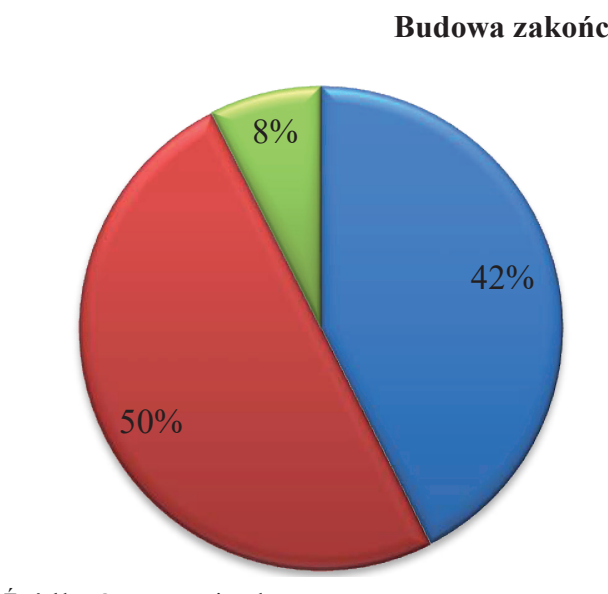

■zakończenia częściowo pogłębione

ⓩakończenie lakoniczne, ogólnikowe

๑brak zakończenia

Źródło: Opracowanie własne.

Porównując budowę zakończeń ze wstępami (por. wykres 2), można zauważyć, że uczniowie o wiele gorzej radzili sobie z redagowaniem zakończeń rozprawek. Aż 50\% maturzystów zredagowało bowiem zakończenia, które były bardzo krótkie i zbyt ogólne. Zaskakujące jest jednak to, że trudności z napisaniem poprawnych zakończeń mieli uczniowie ze wszystkich przedziałów staninowych, por.:

Stąd można wywnioskować że nie zawsze jest to wolna wola człowieka lecz są też siły od niego niezależne (IPP1/1).

Podsumowując stwierdzam, że z jednej strony los ludzki może wynikać z wolnej woli człowieka, a z drugiej strony może decydować o nim siła od niego niezależna (IPP1/4).

Reasumując różnie w życiu bywa. Niekiedy to my decydujemy o naszym życiu, niekiedy robi to za nas los (IPP2/4).

Człowiek może próbować los zmienić, ale nie wie czy odczują to przyszłe pokolenia czy on sam. Los jest panem naszego życia i musimy podlegać jego woli. Niestety czy tego chcemy czy nie, o tym jaki nam los jest pisany decyduje świat (IPP1/6).

Człowieka od innych stworzeń odróżnia to, że posiada zdolność abstrakcyjnego myślenia i rozum. I właśnie rozum, czyli my sami, decydujemy 
o naszym losie. Niektórych rzeczy człowiek nie zmieni, jak choćby pochodzenia społecznego, rodziny czy przeszłości, ale zawsze może zmienić przyszłość. Przyszłość, którą sam kształtuje (IPP2/7).

Jak widać, autorzy tych zakończeń nie odnieśli się do żadnych tekstów kultury. Dwa pierwsze zakończenia były ponadto zbyt schematyczne i ogólne. Maturzyści przywołali w nich bowiem wyłącznie tezy, które postawili we wstępie. Kolejne dwa zakończenia były już bardziej rozbudowane, choć nadal zbyt powierzchowne - zabrakło materiału przykładowego, konkretnych odwołań. Niektóre sformułowania wymagają również ujednoznacznienia.

Mimo że żadne z zakończeń analizowanych rozprawek nie było pogłębione, należy wyróżnić kilka wypowiedzi. Były one przede wszystkim bardziej rozbudowane od tych już zacytowanych, a ponadto zawierały więcej elementów, z których powinno składać się funkcjonalne zakończenie, np.:

W podsumowaniu chciałbym jeszcze raz wrócić do pytania „Wolna wola człowieka czy siły od niego niezależne?". W moich powyższych argumentach widać, że oby dwie te rzeczy się ze sobą przeplatają. Są sytuacje, na które możemy wpłynąć, ale i takie, które są nam narzucone. Myślę, że obydwie te rzeczy mają znaczący wpływ na los człowieka (IPP2/5).

Uważam, że zdarzenia niezależne od nas w większości decydują o naszym losie, ponieważ „nic nie dzieje się bez przyczyny”. Nasza decyzja kreuje się pod wpływem sytuacji, z którymi się zderzamy na co dzień. Choroba czy też walka jak u Baczyńskiego zmienia nasz pogląd i decyzję. Takie wydarzenia nie są zależne od nas. Najważniejsze jest, by kierować się rozumem i należy przemyśleć każdą możliwą opcję. Sami widzimy, że czasem ta decyzja może być bardzo trudna (IPP1/5).

Podsumowując, raz jeszcze powtarzam swoją tezę, że człowiek decyduje o tym, co robi, jednak w ogólnym rozrachunku nie ma to wpływu na koniec, jaki go czeka. Ukazują to podane przeze mnie przykłady. Zarówno Stanisław Wokulski, jak i Makbet, mieli pozorny wpływ na swój los, jednak zakończenia opowiadających o nich historii, pokazują jak niewiele dały ich działania (IPP1/9).

Podsumowując, sądzę iż pytania o wolność człowieka budzą lawinę nowych pytań, a niewiele jest nam wstanie dać pewnych odpowiedzi. Uważam jednak, ze warto przyjąć, iż jesteśmy wolni i że cała odpowiedzialność spoczywa na naszych barkach. Determinizm i fatalizm doprowadza nas do skrajności (lub źle rozumiane) mogą prowadzić do zaniechania prób zmiany świata na lepsze, bo wymówka rodem z „Kociej kołyski” Vonneguta, ulubione stwierdzenia (nazwisko nieczytelne), czyli „tak musiało się 
stać”, jest niezwykle wygodna. Jestem pewna, że warto wybrać wolność i odpowiedzialność, bo, parafrazując Pascala, nie mamy nic do stracenia, a zyskać można dużo satysfakcji i radości (IPP2/9).

W pierwszym z zacytowanych zakończeń autor rozprawki bezpośrednio nawiązuje do tematu pracy i $\mathrm{w}$ bardzo powierzchowny sposób odsyła odbiorcę tekstu do argumentów, które zostały przez niego przywołane. $\mathrm{Z}$ kolei autor pracy IPP1/5 w zakończeniu przedstawia swoje stanowisko i stara się je uzasadnić. Odwołuje się również do Baczyńskiego, którego wiersz pt. Pokolenie został przywołany w rozwinięciu wypracowania. Do tekstów kultury odnosi się w zakończeniu również autor rozprawki IPP1/9. Maturzysta przywołuje także tezę, która została postawiona przez niego we wstępie rozprawki. Najbardziej rozbudowane zakończenie zostało napisane przez maturzystkę (o płci świadczą używane w rodzaju żeńskim formy osobowe), której praca znalazła się w 9 przedziale staninowym. Autorka pracy zbudowała bowiem niestandardowe zakończenie, w którym powołała się na koncepcje filozoficzne. Mimo rozległej wiedzy humanistycznej, którą maturzystka wykazała się w całej pracy, zakończenie budzi pewne wątpliwości co do zgodności z tematem wypracowania, gdyż od niego odbiega. Świadczy o tym choćby następujące zdanie: „Jestem pewna, że warto wybrać wolność i odpowiedzialność [...]".

Analiza budowy części finalnej rozprawek pozwoliła także na wyróżnienie kilku sposobów ich kończenia. Maturzyści najczęściej rozpoczynają swoje zakończenia od finalnych formuł typu: reasumując, podsumowując, rzadziej zaś od zdań twierdzących, których treść stanowi wynik dotychczasowych rozważań piszącego.

W zakończeniach, które nawiązywały do tematu tekstu, zdający przeważnie rozpoczynali jego finalną część od wyrażenia metatekstowego. Posłużenie się takimi formułami sprawia, że pracę należy traktować całościowo. Piszący tekst odsyła bowiem w nim odbiorcę do swoich wcześniejszych rozważań, które w tym miejscu zostaną podsumowane, np.:

Podsumowując, Stanisław oraz Edyp byli tylko ofiarami swoich serc i kar boskich [...] (IPP1/2).

Podsumowując, życie ludzkie pełne jest niesprawiedliwości [...] (IPP1/7).

Podsumowując, raz jeszcze powtarzam swoją tezę, że człowiek decyduje o tym, co robi, jednak w ogólnym rozrachunku nie ma to wpływu na koniec, jaki go czeka [...] (IPP1/9).

Moim zdaniem uważam, że życie człowieka jest po prostu za ciężkie [...] (IPP2/1). 
Uważam, że zdarzenia niezależne od nas w większości decydują o naszym losie, ponieważ „nic się nie dzieje bez przyczyny” [...] (IPP1/5).

Spośród maturzystów 25\% rozpoczęło jednak swoje zakończenia od zdań twierdzących, sentencjonalnych. Jak pisze Tabisz:

Uogólnienia charakterystyczne są nie tylko dla inicjalnych, ale również dla finalnych części tekstów argumentacyjnych, których wywód opierał się na indukcyjnym toku rozumowania. Uczniowie, wychodząc od sądów szczegółowych, dochodzą w zakończeniu do uogólnienia, mającego postać zdania samodzielnego - najczęściej udowodnionej tezy, która [...] uzupełniona jest komentarzem ${ }^{15}$.

Taki sposób kończenia rozprawki ilustrują przykłady:

Człowiek może starać się zmienić swój los. Nigdy jednak nie będzie miał pewności, czy jego działania mają jakiś sens i kto istotnie skorzysta na takiej zmianie (IPP4/6).

Człowieka od innych stworzeń odróżnia to, że posiada zdolność abstrakcyjnego myślenia i rozum [...] (IPP2/7).

\section{Rozwinięcie — realizacja tematu rozprawki}

Rozwinięcie jest najważniejszą częścią rozprawki — to w tej bowiem części wypowiedzi maturzyści przedstawiają swoją argumentację. Przyjrzymy się zatem temu, w jaki sposób autorzy prac realizowali temat.

W poleceniu wymagano od maturzystów, aby rozważyli następujący problem: Wolna wola człowieka czy sity od niego niezależne - co przede wszystkim decyduje o ludzkim losie. W rozprawce uczniowie musieli odwołać się zarówno do Lalki Bolesława Prusa, jak i do innego dowolnego tekstu kultury. Od tego, w jaki sposób maturzyści sformułowali swoje stanowisko we wstępie (teza lub hipoteza), zależała kompozycja rozwinięcia.

$\mathrm{Na} 40$ prac tylko jedna nie była zgodna z treścią polecenia. Jej autor skupiał się bowiem na rozstrzygnięciu innego problemu niż ten, który został sformułowany w temacie:

\footnotetext{
15 A. Tabisz: Kompetencja tekstotwórcza uczniów..., s. 79.
} 
Często słyszymy, że człowiek posiada wolną wole. Być może tak jest, ale czy napewno jeśli chodzi o uczucia? [...] Człowiek posiada wolną wole ale też jest czas w jego życiu gdy tej wolnej woli ma. Mowa jest o czasie kiedy owy człowiek dozna zauroczenia drugą osobą, kiedy to zakochał się w jej wyglądzie. Jest to tak zwane zauroczenie, które trwa kilka miesięcy. Właśnie te kilka miesiecy jest takim czasem gdzie podejmowanie decyzji, może nie być do końca racjonalne ponieważ robimy wszystko by zaimponować tej właśnie osobie nie myśleć o tym czy to będzie dobre dla nas samych [...]. Pan Wokulski stracił głowe dla panny Rzegockiej, kupił dom od jej Ojca za cene przewytającą jego wartość. Zrobił to by zaimponować dziewczynie, która leci na bogatych mężczyzn [...] (IPP3/1).

Jak widać, autor tej pracy stara się wpleść do niej zagadnienia związane $\mathrm{z}$ wolną wolą, ale właściwie w całym wypracowaniu zastanawia się nad wpływem wolnej woli na uczucia człowieka, a nie nad jej wpływem na ludzki los. Ponadto w rozprawce popełnił on błąd kardynalny — w Lalce nie ma bowiem bohaterki panny Rzegockiej. Jest panna Izabela Łęcka i subiekt Ignacy Rzecki (nazwisko Rzegocka to zapewne kontaminacja nazwisk Łęcka i Rzecki).

Ponad $15 \%$ prac stanowiły z kolei streszczenia zamieszczonego w arkuszu fragmentu Lalki. Ich autorzy problem, z którym mają się zmierzyć, sygnalizowali we wstępie, w zakończeniu przedstawiali zaś wnioski (w jednej z prac nie było finalnej części rozprawki), ale rozwinięcie tematu wypracowania nie miało charakteru argumentacyjnego, por.:

Według mnie o losie ludzkim decydują siły od niego niezależne ponieważ jak wspomniał Bolesław Prus w fragmencie z „Lalki” „Zatem praca milionów ludzi, którzy tak głośno krzyczą o swojej wolnej woli, wydaje te same skutki, co praca pszczół, budujących regularne plastry, mrówek wznoszące regularne kopce [...]". Tak jak też wspomniał Paryżem rządzili różni władcy tacy jak [...]. A paryż nadal ma ten kształt „Półmiska rozdartego przez Sekwane" $[\ldots]$ (IPP1/1).

W „Lalce” został opisany bohater, którym jest nim Wokulski. Wokulski jest skromnym rzemieślnikiem, dziadem, również pracował przy ulicy Temple po szesnaście godzin na dobę. Ulica Temple w tekście jest pokazana jako [...]. Wokulski miał syna, który założył warsztat przy ulicy Świętego Antoniego. Miał też wnuka i prawnuka. Jego wnuk mieszkał w dzielnicy, gdzie przeniósł się tam jako wielki handlarz, natomiast jego prawnuk był milionerem i mieszkał w sąsiedztwie Pól Elizejskich. Cała rodzina Wokulskiego mieszkała w Paryżu [...] (IPP2/1).

Pierwszej z cytowanych prac brakowało zamysłu kompozycyjnego. Jej autor w nieumiejętny sposób wprowadzał cytaty z Lalki, które stanowiły większą 
część pracy będącej nieudolnym streszczeniem zamieszczonego pod poleceniem fragmentu powieści. Druga z przytoczonych prac również jest streszczeniem Lalki; jej autor popełnia także i inne błędy, w tym kardynalne — źle zrozumiał bowiem fragment, w którym narrator przytacza historię jednej z paryskich rodzin. Maturzysta uznał, że jest to historia rodziny Wokulskiego. Ten rażący błąd wynika $\mathrm{z}$ braku znajomości treści lektury.

Pozostali maturzyści budowali wypowiedzi zgodne z wyznacznikami gatunkowymi rozprawki. W ponad $90 \%$ prac przyjmowali dedukcyjny tok rozumowania. Przeprowadzana argumentacja nie zawsze była jednak pogłębiona (por. wykres 5).

\section{Argumentacja - rozprawka}

Wykres 5

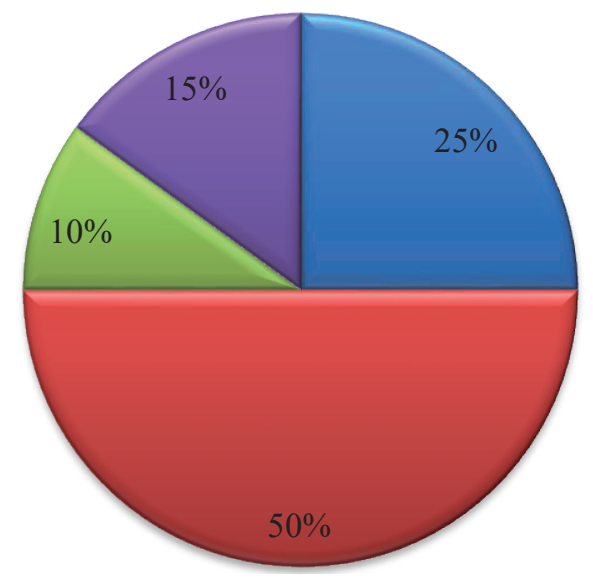

ロ argumentacja pogłębiona

■argumentacja częściowo pogłębiona

$\square$ argumentacja niepogłębiona

๑brak argumentacji

Źródło: Opracowanie własne.

Za rozprawki pozbawione części argumentacyjnej uznałam te, które w dużej mierze były streszczeniem powieści Prusa. Stanowią one 15\% wszystkich prac. Kolejne $10 \%$ to wypracowania, w których autorzy przedstawili argumentację niepogłębioną, tzn. miały one charakter dowodu, ale bez uzasadnienia, por::

Kolejnym przykładem, gdzie własna wola bohatera nie miała wpływu na jego los jest utwór Franza Kafki pochodzący z dwudziestolecia międzywojennego pt. „Proces”. Bohaterem utworu jest Józef K. Człowiek spokojny, pracujący w banku. Pewnego dnia zostaje on aresztowany, nie znając powodu zatrzymania [...]. Ten przypadek odzwierciedla położenie człowieka w systemie totalitarnym, gdzie nikt nie liczy się z ludzkimi prawami (IPP1/3). 
Kolejnym utworem potwierdzającym słuszność tezy jest „Granica” Zofii Nałkowskiej. Bohaterem jest Zenon Ziembiewicz, który będąc w związku małżeńskim z Elżbietą Biecką romansuje z Justyną. Czyn ten doprowadza do tego, że z własnej woli skrzywdził on dwie bliskie mu kobiety, po czym sam poniósł karę wymierzoną mu przez Justynę (IPP2/4).

Zamiarem autorów prac, których fragmenty przytoczyłam, było włączenie w tok wywodu racjonalnych argumentów. Niestety, pierwszy z maturzystów zbyt dużo miejsca poświęcił na streszczenie utworu. $Z$ kolei drugi ze zdających rozwinął argument w sposób bardzo powierzchowny. Obaj zapomnieli o tym, że argument powinien odwoływać się do ich tezy, stanowić jej pewne uzasadnienie i, co najważniejsze, przekonać odbiorcę do słuszności zajmowanych stanowisk.

Argumentacja częściowo pogłębiona występowała w 50\% prac. Argumenty miały charakter dowodu, ale zawierały również uzasadnienie, które jednak wymagało zazwyczaj szerszego rozwinięcia. Tylko w 25\% rozprawek argumentację można uznać za pogłębioną. Były to prace pochodzące z 7, 8 i 9 przedziału staninowego.

Wśród najczęściej pojawiających się typów argumentów wyróżnić można tzw. argumenty racjonalne (zawierają rzeczową informację). Występowały jednak i takie prace, w których autorzy w nieuzasadniony sposób odwoływali się do doświadczeń osobistych, np.:

Tak jak już wspomniałam, nie sposób przyznać całkowitej racji jednej ze stron. Dlaczego bowiem siedzę tu teraz i piszę te słowa? Czy to wynik moich własnych starań, czy akurat taka rola została dla mnie dziś przewidziana? Czy jestem marionetką, aktorem na scenie świata, jak mówi wywodzący się ze starożytności topos theatrum mundi? A może, jak twierdził Baruch Spinoza, chyba najsłynniejszy z panteistów, Bóg jest tożsamy $\mathrm{z}$ naturą, a każdy z nas jest częścią tego ustanowionego z góry porządku (IPP2/9).

Moim zdaniem uważam, że życie człowieka jest po prostu za ciężkie. Czasem nawet się poddajemy jak już nie mamy siłę i jak nam brakuje wolnej woli. W innych lekturach jest mowa o losach ludzkich, ale najbardziej jest ciężko to opisać przy używaniu własnych słów (IPP2/1).

Wolna wola czy ślepy los? W moim życiu najczęściej do głosu dochodzi zrządzenie losu, przypadek. Rzadko to ja tak w stu procentach decyduję o sobie i swoim życiu (IPP 4/5).

Analiza wszystkich prac pozwoliła na wysunięcie wniosku, że maturzyści właściwie nie zdawali sobie sprawy z tego, że przytaczane przez nich argumenty 
powinny być ułożone w jakimś ściśle określonym porządku — od najsłabszego do najsilniejszego, od najsilniejszego do najsłabszego — bądź w porządku nestoriańskim (mocny, słaby, mocny). Przywoływane argumenty miały w zasadzie równoważną moc.

W treści polecenia maturzystów poproszono również o odwołanie się do innego tekstu kultury. W 60\% rozprawek ich autorzy nawiązywali do jednego innego niż Lalka tekstu. W 30\% wypracowań uczniowie przywołali dwa (15\%) lub trzy (także 15\%) wybrane przez siebie przykłady. Tylko w 10\% wszystkich prac nie odnotowałam odwołań do innej niż Lalka lektury. Maturzyści najczęściej sięgali do tekstów z kanonu literackiego (prawie 93\% wszystkich prac). Siedmioro spośród zdających przywołało tragedię Sofoklesa Król Edyp; pięcioro - Biblię; czworo - Makbeta Williama Szekspira; czworo - mity greckie. Maturzyści odwoływali się także do Granicy Zofii Nałkowskiej, Zbrodni i kary Fiodora Dostojewskiego, Dżumy Alberta Camusa, Poczwarki Doroty Terakowskiej. Tylko w dwóch pracach uczniowie sięgnęli po inne niż lektury szkolne teksty kultury - film Bogowie w reżyserii Łukasza Polkowskiego oraz po biografię Gustawa Herlinga-Grudzińskiego.

\section{Rozczłonkowanie treściowe i graficzne}

Nie można zapomnieć także o roli akapitu w tekstach pisanych. Akapit ${ }^{16}$ jest najistotniejszym elementem dla ich struktury, przede wszystkim sprzyja podążaniu za autorem, ułatwia także interpretację czytanej pracy. Jolanta Maćkiewicz zwraca uwagę na to, by nie traktować akapitu wyłącznie jako sposobu segmentacji tekstu, pisze także o dwóch sposobach jego funkcjonowania: akapit to element tekstu i jednocześnie tekst w miniaturze, na który również składa się wstęp, rozwinięcie i zakończenie ${ }^{17}$. Odwołując się do ustaleń autorki, w analizie budowanych przez uczniów akapitów uwzględnię zarówno ich zewnętrzną (akapit jako element tekstu), jak i wewnętrzną budowę (akapit jako tekst w miniaturze).

Rozumienie akapitu jako elementu tekstu wiąże się z jego graficznym przedstawieniem. Taka segmentacja nie tylko ułatwia rozumienie danego tekstu, ale

${ }^{16}$ Akapit — ,wyodrębniony graficznie fragment tekstu wyrażający (zazwyczaj) jedną myśl i składający się z powiązanych ze sobą zdań”. E. Łuczyński, J. Maćkiewicz: Językoznawstwo ogólne. Wybrane zagadnienia. Gdańsk 2002, s. 91.

${ }_{17}$ Zob. J. Maćkiewicz: Akapit. W: Eadem: Jak dobrze pisać. Od myśli do tekstu. Warszawa 2010, s. 115-118. Zob. także: E. Wolańska: Kompozycja i spójność wypowiedzi językowej. Strategiczne pozycje tekstowe. W: Praktyczna stylistyka nie tylko dla polonistów. Red. E. Bańkowska, A. Mikołajczuk. Warszawa 2003, s. 119-148. 
także go porządkuje. Akapity muszą być wyodrębniane w sposób logiczny, a także konsekwentnie stosowane. Choć graficzne wyodrębnianie kolejnych akapitów wydaje się zadaniem łatwym, to jednak niewielu maturzystów potrafi w poprawny sposób stosować charakterystyczne wcięcie z lewej strony. W ich pracach można zaobserwować m.in.: brak akapitów; brak konsekwencji w segmentacji tekstu; zaznaczanie akapitów w przypadkowych miejscach, co nierzadko utrudnia odbiorcy orientację w myślowej strukturze tekstu.

\section{Zewnętrzna segmentacja tekstu — graficzne wyodrębnienie kolejnych akapitów}

Wykres 6

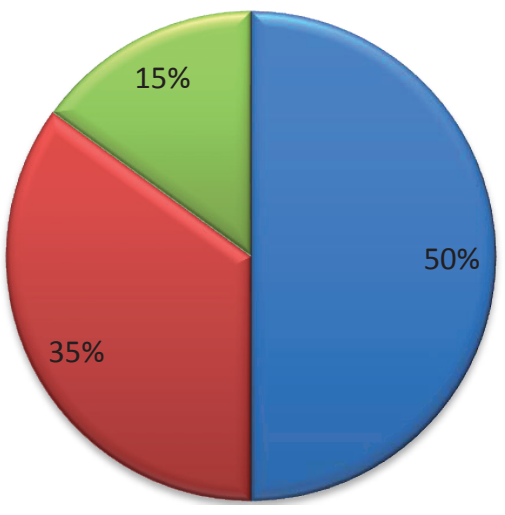

๑prawidłowa zewnętrzna segmentacja tekstu

zaburzenia zewnętrznej segmentacji tekstu

$\square$ brak zewnętrznej segmentacji tekstu

Źródło: Opracowanie własne.

W 15\% rozprawek, na które składają się teksty pochodzące z 1 i 2 przedziału staninowego, w ogóle nie zastosowano podziału na akapity. Kolejne 35\% prac stanowią te, w których akapity zostały wprowadzone w sposób niefunkcjonalny, np.:

W mojej poniższej pracy będę rozwiązywała problem, który został przedstawiony $\mathrm{w}$ temacie oraz $\mathrm{w}$ poniższym tekście utworu.

W poniższym fragmencie utworu Bolesława Prusa pod tytułem „Lalka” został przedstawiony problem człowieka i jego życia oraz też całego społeczeństwa.

W „Lalce” został opisany bohater, który [...] (IPP2/1).

Każdy człowiek posiada własną wolę, ma zdolność decydowania o swej przyszłości. Jednak zazwyczaj o ludzkim losie decydują zdarzenia od niego niezależne.

Uważam, iż o losie człowieka przedewszystkim decydują siły od niego niezależne. W podanym fragmencie pozytywistycznego utworu Bolesława Prusa, pt. „Lalka” możemy dostrzec tę zależność (IPP1/3). 
Niefunkcjonalność takiego podziału na akapity wynika z tego, że maturzyści nie dostosowali się do jednej z głównych zasad dotyczących wewnętrznej segmentacji tekstu - jeden akapit powinien bowiem zawierać jedną myśl. Na podstawie zacytowanych fragmentów prac można zauważyć, że ich autorzy stosowali zasadę: nowe zdanie - nowy akapit. Istotne jest także to, że w obu przypadkach nie można mówić o konsekwencji maturzystów w dokonywaniu podziału na akapity. Zasada: nowe zdanie — nowy akapit była bowiem stosowana tylko do pewnego momentu.

Wśród rozprawek 50\% stanowiły takie prace, w których wewnętrzna segmentacja tekstu została wykonana prawidłowo. Ilość akapitów była przy tym uzależniona od liczby wprowadzonych argumentów. Schemat takich rozprawek przedstawiał się zatem następująco: wstęp - argumentacja (argument 1, argument $2, \ldots)$ - zakończenie.

Dokonując podziału na akapity, maturzyści najczęściej nie zapominali o tym, by były one zrównoważone objętościowo — akapity nie powinny być bowiem zbyt krótkie, ale i aż nadto rozbudowane. Problemem dla wielu piszących było natomiast zachowanie spójności nie tylko wewnątrz danego akapitu, ale i pomiędzy akapitami sąsiadującymi z sobą, por.:

Wracając do dzieła Bolesława Prusa pt. „Lalka” możemy twierdzić, że wolną wolą Wokulskiego była chęć wzięcia za żonę Izabeli Łęckiej, lecz do skutku to nie doszło z powodu braku wzajemnego uwielbienia.

Podsumowując wolna wola jest bardzo ważna w życiu człowieka, dużo zależy od naszej wolnej woli, jak i woli naszych przodków. Nic się nie dzieje bez przyczyny, a tą przyczyną zawsze są czyny nasze bądź innych (IPP1/2).

Każdy człowiek posiada własną wolę, ma zdolność decydowania o swej przyszłości. Jednak zazwyczaj o ludzkim losie decydują zdarzenia od niego niezależne.

Uważam, iż o losie człowieka przedewszystkim decydują siły od niego niezależne (IPP1/3).

Często słyszymy, że człowiek posiada wolną wole. Być może tak jest, ale czy na pewno jeśli chodzi o uczucia?

Człowiek roztropny, pochodzący z ubogiej rodziny to dorabiający się majątku, znający język. Mimo tego wszystkiego owy człowiek ma uczucia. Uczucia które odezwały się w nim po zobaczeniu jednej osoby, mowa o Pannie Rzegockiej curce filantropa. Uczucia są niezależne od nas, każdy człowiek je posiada, jeśli zakocha się na zabój, może zrobić dla drugiej osoby wszystko, nawet swoje życie. O wolnej woli można mówić gdy [...] (IPP3/1). 
W żadnym z zacytowanych fragmentów nie zachowano spójności pomiędzy akapitami. Właściwie nie łączą się one z sobą i tym samym mogłyby funkcjonować samodzielnie - usunięcie jednego z akapitów nie naruszyłoby struktury całego tekstu. W ostatnim z przytoczonych fragmentów nie zachowano ponadto spójności semantycznej w obrębie samego akapitu. Poszczególne zdania nie łączą się bowiem z sobą.

Wśród typów akapitów $\mathrm{w}$ analizowanych pracach najczęściej występują akapity syntetyczne, w których wypowiedzenie tematowe ulokowane było na końcu. Taki typ akapitu pełni ,zazwyczaj funkcję wniosku, którego przesłanki zawarte są w rozwinięciu, lub puenty, efektownie zamykającej wywód"18.

$\mathrm{W}$ maturalnych wypracowaniach akapity syntetyczne pełniły wyłącznie funkcję wniosku, np.:

Domyśleć się można, iż dziad rzemieślnik nie planował dążyć do tego, aby jego potomkowie wspinali się coraz wyżej po szczeblach klas społecznych. O losie miasta i jego mieszkańców zdecydowały więc siły od nich nie zależne ${ }^{19}$ (IPP1/3).

Podsumowując, Stanisław oraz Edyp byli tylko ofiarami swoich serc i kar boskich. Każdy człowiek oddziałowywuje na to co jest w pobliżu. Na to co jest w pobliżu nie mamy żadnego znaczenia. Więc przede wszystkim o losie czlowieka decydują rzeczy niezależne (IPP2/1).

Właściwie równie często, jak akapity syntetyczne, w pracach maturzystów pojawiały się akapity analityczne. Wypowiedzenie tematowe $\mathrm{w}$ tym wypadku znajdowało się na początku, nadając przy tym sens porządkujący treściom, które były rozwijane w dalszej części danego akapitu ${ }^{20}$. Dla przykładu:

Kolejnym przykładem, gdzie własna wola bohatera nie miała wpływu na jego los jest utwór Franza Kafki pochodzący z dwudziestolecia międzywojennego pt. „Proces” [...] (IPP1/3).

Los ludzki $\mathrm{z}$ jednej strony może wynikać $\mathrm{z}$ wolnej woli człowieka, a z drugiej strony może decydować o losie sila od niego niezależna. Los każdego człowieka potacza się zupełnie inaczej [...] (IPP1/4).

Bardzo rzadko maturzyści stosowali tzw. akapity nieklasyczne, w których wypowiedzenie tematowe ulokowane było w środku akapitu, np.:

18 J. Maćkiewicz: Akapit. W: Eadem: Jak dobrze pisać..., s. 120.

19 Wyróżnienia (pogrubienia) w przywoływanych cytatach z prac maturalnych wprowadziła autorka artykułu.

${ }^{20}$ Zob. ibidem, s. 118. 
Życie każdego człowieka jest niepowtarzalne, dlatego stanowi od wieków przedmiot rozważań filozofów. Kwestia, czy czlowiek ma wplyw na własny los, to jeden z głównych problemów egzystencjalnych. Świadczą o tym dążenia znanych myślicieli, a w szczególności św. Augustyna, do podporządkowania świata bytowi idealnemu, który nadałby sens dziejom ludzkości. Dziś zatem możemy wysnuć wniosek, że los jest niezależny od wolnej woli człowieka, także światem kieruje wyższa siła (IPP1/7).

Człowieka od innych stworzeń odróżnia to, że posiada zdolność abstrakcyjnego myślenia i rozum. I wlaśnie rozum, czyli my sami, decydujemy o naszym losie. Niektórych rzeczy człowiek nie zmieni, jak choćby pochodzenia społecznego, rodziny czy przeszłości, ale zawsze może zmienić przyszłość. Przyszłość, którą sam kształtuje (IPP2/7).

Jak widać, autorzy prac mieli spore problemy z poprawnym zredagowaniem akapitów. Nie było bowiem takiej pracy, w której byłyby one właściwie rozczłonkowane zarówno graficznie, jak i treściowo. Trudne było także dla maturzystów zachowanie spójności nie tylko pomiędzy akapitami, lecz także wewnątrz nich. Zapomnieli bowiem, iż akapit jest tekstem w miniaturze, a „kolejne akapity pozostają względem siebie w [...] relacji”"21.

Analiza 40 rozprawek napisanych na poziomie podstawowym pozwoliła na sformułowanie kilku uogólnień. Przede wszystkim największe problemy zdający mają z budowaniem zakończeń i to niezależnie od tematu pracy, formy gatunkowej czy przedziału staninowego. Części finalne są bardzo ogólne, ograniczają się do zaledwie kilku zdań, nie zawierają odwołania do wywodu argumentacyjnego, bardzo rzadko piszący przywołują w nich tezę. Kłopoty sprawiło też maturzystom zredagowanie funkcjonalnych, pełnych ze względu na podjęty temat wstępów, choć te na ogół są bardziej rozbudowane od zakończeń. Uczniowie stosunkowo często nie formułowali we wstępach stanowiska, które będą starali się uargumentować w dalszej części pracy, lub było one przedstawione przez nich w sposób niejasny, wymagający doprecyzowania. Z postawieniem tezy lub hipotezy (te pojawiły się zaledwie w dwóch z czterdziestu prac) zdecydowanie lepiej radzili sobie ci maturzyści, którzy zdecydowali się na interpretację utworu poetyckiego. Argumentacja w prowadzonych wywodach bardzo rzadko była pogłębiona. Niektóre wypowiedzi były nieprecyzyjne, a argumenty nietrafne. Piszący rzadko hierarchizowali przywoływane argumenty — były one zazwyczaj dobrane w sposób przypadkowy, miały równoważną moc lub okazywały się nieprzekonujące. Często uczniowie powoływali się na własne doświadczenia.

${ }^{21}$ J. Bartmiński, S. Niebrzegowska-Bartmińska: Tekstologia. Warszawa 2009, s. 257. 
W zadaniu egzaminacyjnym poproszono maturzystów, by odwołali się do innego tekstu kultury. Nie wszyscy piszący rozprawkę spełnili tę część polecenia, odwołując się do wybranych przez siebie, najczęściej literackich, kontekstów.

W sporej części prac można było także zaobserwować trudności w segmentacji treściowej i graficznej tekstów. Niektórzy uczniowie nie zaznaczali akapitów wcięciem lub wprowadzali je w niewłaściwych miejscach. Mimo że maturzyści nie mieli właściwie problemu z zachowaniem stosowności wypowiedzi, wielu z nich zbyt często używało wyrazów potocznych, zapewne nieświadomie. Maturzyści popełniali także liczne błędy językowo-stylistyczne, ortograficzne $\mathrm{i}$ interpunkcyjne ${ }^{22}$. Niektórzy nie radzili sobie nawet $\mathrm{z}$ zapisem ortogramów o wysokiej frekwencji w różnego typu tekstach, w tym tekstach omawianych na lekcjach języka polskiego. Także prawidłowe stosowanie znaków interpunkcyjnych sprawiało piszącym wiele trudności. Popełniali w tym zakresie wiele błędów, w tym rażących. Odnotowałam m.in.:

— nagminne pomijanie przecinka bądź przecinków w wypowiedzeniach $\mathrm{z}$ imiesłowowym równoważnikiem zdania oraz drugiego przecinka $\mathrm{w}$ wypowiedzeniu z członem wplecionym (wtrąconym);

- bardzo częste opuszczanie przecinka przed zaimkiem jaki (jaka,jakie...);

— stawianie przecinka przed spójnikiem $a$, który wystąpił w połączeniu z przyimkiem między lub pomiędzy;

- pomijanie przecinka przed spójnikiem jak wprowadzającym wyliczenie i wyszczególnienia;

— pomijanie przecinka przed drugim członem spójnika złożonego (zarówno..., jak $i \ldots$ );

— częste rozdzielanie przecinkiem połączeń: mimo że, pomimo że, zwłaszcza $\dot{z} e, j a k o \dot{z} e$;

— oddzielanie średnikiem członów nierównorzędnych pod względem logiczno-składniowym;

- pomijanie przecinka przed spójnikami przeciwstawnymi, wynikowymi, synonimicznymi, pomijanie przecinka lub myślnika zamykającego przy wypowiedzeniu wtrąconym.

Maturzyści popełniali także liczne błędy wewnątrzjęzykowe: składniowe (najliczniejsze), słownikowe, frazeologiczne, fleksyjne. Najwięcej jednak odnotowałam różnego typu błędów stylistycznych ${ }^{23}$.

Niezależnie od formy gatunkowej wypracowania czy też jego tematu musi być ono spójne. Dlatego analizując ukształtowanie wypracowań maturalnych, zwracałam także uwagę na wykorzystywane przez maturzystów mechanizmy

${ }^{22}$ Część z nich można zauważyć już w cytowanych przeze mnie pracach. Jako przykłady błędów podaję te, które nie pojawiły się w przytoczonych w tekście fragmentach.

${ }^{23}$ Jest to materiał na odrębny artykuł. 
spójności tekstu. Większość uczniów nie miała problemów z zachowaniem spójności lokalnej. Spośród zdających $67 \%$ zadbało o to, by ich wypowiedzi były logiczne i uporządkowane pod względem gramatycznym. Starali się zachować spójność nie tylko wewnątrz zdań, ale i pomiędzy nimi, a także pomiędzy sąsiadującymi z sobą akapitami. Kohezję osiągali przede wszystkim przez:

— stosowanie synonimów, np.:

Kolejnym utworem potwierdzającym słuszność tezy jest „Granica” Zofii Nałkowskiej [...]. Następnym przykładem jest „Makbet” Williama Szekspira [...] (IPP2/4).

— wprowadzanie podmiotu domyślnego, np.:

Człowiek, jako istota rozumna, obdarzona wolną wolą, ma oczywiście zdolność podejmowania własnych decyzji i działań. W gruncie rzeczy nie wie jednak nigdy, dokąd tak naprawdę zmierza, nawet jeśli „podąża własną drogą" [...] (IPP1/9).

— stosowanie powtórzeń, np.:

Los ludzki z jednej strony może wynikać z wolnej woli człowieka, a z drugiej strony może decydować o losie siła od niego niezależna. Los każdego człowieka potacza się zupełnie inaczej [...] (IPP1/4).

— używanie spójników, np.:

Człowiek jako pojedyńcza jednostka nie jest w stanie wszystkiego przewidzieć i mieć na wszystko wpływ. Lecz ciężką praca może poprawić każdą sytuację, może wszystko zmienić (IPP2/3).

Uważa, że zdarzenia niezależne od nas w większości decydują o naszym losie, ponieważ „nic nie dzieje się bez przyczyny”. Nasza decyzja kreuje się pod wpływem sytuacji, z którymi zderzamy się na codzień $[\ldots]$ (IPP1/5).

Ludzie oraz to, co z nimi związane to główny temat poruszany od wieków w literaturze. Pisarze skupiają się na człowieku, jego psychice, życiu. Przedstawiają go w różnoraki sposób - jako silnego bądź słabego, dobrego lub złego i zepsutego. Jednak co, tak naprawdę, decyduje o ludzkim losie? [...] (IPP1/8).

— stosowanie przyimków i wyrażeń przyimkowych, np.: 
Uważa, że zdarzenia niezależne od nas w większości decydują o naszym losie, ponieważ „nic nie dzieje się bez przyczyny”. Nasza decyzja kreuje się pod wpływem sytuacji, z którymi zderzamy się na codzień [...] (IPP1/5).

Więc według mnie po przedstawieniu tych przykładów stwierdzam że nie jest to wolna wola lecz siła od niego niezależna (IPP1/2).

By nadać swoim tekstom spójność, piszący wykorzystywali także zaimki osobowe (np. on, ona, oni), dzierżawcze (np. jego, jej, ich), nieokreślone (np. gdzieś, jakiś, kiedyś), upowszechniające (np. niektórzy, wszyscy, każdy, zawsze) bądź przeczące (np. nikt, nigdzie); również operatory metatekstowe, np. Moim pierwszym argumentem... Moim drugim argumentem; Drugim przykładem...; Z kolei...

Maturzyści zachowali ponadto jedność tematyczno-rematyczną wypowiedzi (np. Kwestia, czy człowiek ma wpływ na własny los, to jeden z głównych problemów egzystencjalnych. Świadcza o tym dążenia znanych myślicieli, a w szczególności św. Augustyna, do podporządkowania świata bytowi idealnemu, który nadałby sens dziejom ludzkości; Stanisław Wokulski sam jest dobrym przykładem bohatera, który postanowit „wziąć sprawy w swoje ręce”. Dzięki swojej przedsiębiorczości wzbogacit się podczas wojny i sukcesywnie zwiększat swój majątek), nawiązywali do swoich wcześniejszych ustaleń (np. Jak już wspomniałam...; Pisałem już, że...; Wcześniej wspomniałem, iż..; Z moich wcześniejszych ustaleń wynika, że...; Podsumowując to, co wcześniej napisatam...), a poszczególne akapity łączyli z sobą, wykorzystując w tym celu tranzycje (np. Kolejnym przykładem...; Moim następnym argumentem jest to, że...; Pierwszym/drugim argumentem przedstawiajacym słuszność mojej tezy jest...) i zachowując jedność tematyczną wypowiedzi.

W 8\% wszystkich prac kohezja tekstu została jednak w znacznym stopniu zaburzona, np.:

Co najdziwniejsze nie mieli przez tyle czasu planów, a jakoś udało im sie uzyskać taki kształt przez tak długi okres budowy więc coś nadzwyczajnego musi w tym być. Było jeszcze coś, jak zauważył to Wokulski z opowieści kilku rodzin była dość duża rozbieżność związanym z zawodem [...] (IPP1/1).

Często słyszymy, że człowiek posiada wolną wole. Być może tak jest, ale czy na pewno jeśli chodzi o uczucia. Człowiek roztropny, pochodzący z ubogiej rodziny to dorabiający się majątku, znający język. Mimo tego wszystkiego owy człowiek ma uczucia. Uczucia które odezwały się w nim po zobaczeniu jednej osoby, mowa o Pannie Rzegockiej curce filantropa. Uczucia są niezależne od nas, każdy człowiek je posiada, jeśli człowiek za- 
kocha się na zabój, może zrobić dla drugiej osoby wszystko, nawet swoje życie. O wolnej woli człowieka można mówić gdy [...] (IPP3/1).

Według Wokulskiego Paryż przybrał formę półmiska, rozdartego przez Sekwanę. Mimo tego, że francuzami rządziło wiele dynastii, mimo wielu ustrojów politycznych, zmian ministrów itd. Paryż nadal przybierał tą określoną formę. Wokulski porównał tą schematyczną pracę francuzów do $[\ldots](\operatorname{IPP} 1 / 3)$.

Jak widać, poszczególne zdania $\mathrm{w}$ zacytowanych pracach nie łączą się z sobą. Nie ma w nich ani środków nawiązania, ani jedności tematycznej, np. autor pracy IPP3/1 w pierwszych dwóch zdaniach pisze o wolnej woli, a już w kolejnym charakteryzuje jednego z bohaterów Lalki. Brak spójności lokalnej w tych pracach może wynikać z tego, że ich autorzy pisali swoje teksty na zasadzie luźnych skojarzeń, które im się nasuwały. Nie mieli zatem jakiejś określonej koncepcji zredagowania swojego tekstu.

W 25\% wypracowań spójność lokalna była z kolei zaburzona w nieznacznym stopniu, maksymalnie w dwóch miejscach, co może wynikać z chwilowej nieuwagi maturzystów. Przykładowo:

Ulica Temple w tekście jest pokazana jako ulica rzemieślników i uboższego mieszczaństwa. Wokulski miał syna, który założył warsztat $[\ldots]$ (IPP2/1).

Ten przypadek odzwierciedla położenie człowieka w systemie totalitarnym, gdzie nikt nie liczy się z ludzkimi prawami. W obydwóch przypadkach można zauważyć zależność ludzkiej woli do nieplanowanych zdarzeń $[\ldots]($ IPP $1 / 3)$.

Niezachowanie spójności lokalnej tekstu nierzadko powodowało trudności z utrzymaniem spójności globalnej. Jeśli bowiem poszczególne zdania i akapity nie łączyły się z sobą, to odebranie tekstu jako całościowego komunikatu było utrudnione.

\section{Wnioski z badań}

$\mathrm{Na}$ podstawie analizy zgromadzonego materiału badawczego sprawność tekstotwórczą maturzystów należy ocenić jako przeciętną. Nie potrafili bowiem stworzyć wypowiedzi zgodnej z określonym wzorcem gatunkowym - mają 
spore trudności z budową wstępów i zakończeń, ich pracom brakowało zamysłu kompozycyjnego, a części argumentacyjne nie zostały retorycznie zorganizowane. Prezentowali także niski stopień sprawności językowej — w ich wypracowaniach pojawiały się liczne potocyzmy, anakoluty, niekiedy potoki składniowe. Wypowiedzi często były nieprecyzyjne. Najwięcej problemów mieli z zachowaniem poprawności w zakresie ortografii i interpunkcji. Stworzyli jednak wypowiedzi komunikatywne, a tylko pojedyncze prace lub ich fragmenty okazały się trudne do zrozumienia.

Analiza wypracowań dostarczyła wielu istotnych informacji temat kompetencji tekstotwórczej maturzystów: wykorzystali oni tylko część zdobytej w toku nauki wiedzy i wykształconych umiejętności. Przyczyn tego stanu rzeczy należy doszukiwać się już w zapisach w Podstawie programowej ${ }^{24}$. Ich ogólnikowość sprawia, że nauczyciele często mają problemy z określeniem, czego tak naprawdę należy wymagać od ucznia, jaką wiedzę i jakie umiejętności powinien on zdobyć, co będzie sprawdzane na egzaminie maturalnym. Mimo wpisanego w ministerialny dokument tekstocentryzmu brakuje w nim wielu pojęć z zakresu retorycznej organizacji tekstu (poziom wiedzy) i ich funkcjonalnego przełożenia na konkretne sprawności (poziom umiejętności). Sama wiedza o tekście nie wystarczy.

Drugiej przyczyny stosunkowo niskiej sprawności tekstowej należy doszukiwać się w braku umiejętności sfunkcjonalizowania zdobytej wiedzy. $\mathrm{Na}$ lekcjach języka polskiego wciąż bowiem dominuje dyskurs literaturoznawczy, a kształceniu umiejętności tekstotwórczych poświęca się niewiele miejsca. Uczniowie powinni wykonywać jak najwięcej ćwiczeń redakcyjnych oraz językowych i stylistycznych. Kompetencję tekstotwórczą należy nieustannie ćwiczyć i doskonalić. Jej rozwój wiąże się z poszerzaniem zasobu leksykalnego uczniów, pogłębianiem ich świadomości stylowej, doskonaleniem sprawności poprawnego i trafnego władania różnymi strukturami składniowymi, rozbudowywaniem repertuaru form wypowiedzi. Jest to więc proces żmudny i wieloetapowy, wymagający wielu ćwiczeń: słownikowo-frazeologicznych, stylistycznych, kompozycyjnych, redakcyjnych. Trzeba jednak pamiętać, że same ćwiczenia nie wystarczą. Konieczna jest praktyka pisarska - podejmowanie przez ucznia prób wypowiadania się w różnych gatunkach i na różne tematy, nie tylko te odnoszące się bezpośrednio do wiedzy przedmiotowej. Warto tematy wypracowań odstereotypizować, zaproponować np. redagowanie humorystycznych opowiadań, rozprawek, których teza jest nietypowa (zabawna, zaskakująca, kontrowersyjna), uzupełnianie wypracowań, które mają już wstępy i zakończenia ${ }^{25}$.

${ }^{24}$ Podstawa programowa z komentarzami. Język polski $w$ szkole podstawowej, gimnazjum i liceum. Warszawa 2008.

${ }^{25}$ Można wykorzystać takie tematy: Koleżanka siedziała zapłakana w szkolnej szatni. Napisz opowiadanie z dialogiem, w którym przedstawisz możliwą przyczynę przywołanej sytuacji; $\mathrm{Na}$ języku polskim nasza nauczycielka mówiła, że to dobra i pożyteczna książka, a Tobie się ona 
W tym celu nauczyciele powinni wykorzystywać także różne metody i techniki nauczania. Uczniowie stosunkowo często powinni także napisane teksty wygłaszać. Tylko w taki sposób uświadomią sobie retoryczne i pragmatyczne aspekty komunikacji językowej.

\section{Bibliografia}

Bartmiński J., Niebrzegowska-Bartmińska S.: Tekstologia. Warszawa 2009.

Bartosiewicz D.: Sprawność tekstotwórcza jako integralny element oceny pisemnych prac maturalnych. W: Nowa matura a egzamin wstępny z języka polskiego. Red. R. Pawłowska. Gdańsk 2001 .

Diagnoza kompetencji gimnazjalistów. Język polski. Warszawa 2013.

Informator o egzaminie maturalnym z języka polskiego od roku szkolnego 2014/2015. Warszawa 2013.

Krzyżyk D.: Umiejętności tekstotwórcze i językowe uczniów w pisemnych pracach maturalnych. W: Kształcenie językowe w dobie kultury masowej polisensorycznej. Red. U. Kopeć, Z. Sibiga. Rzeszów 2010.

Krzyżyk D.: Wyznaczniki spójności tekstu w pracach pisemnych maturzystów. „Biuletyn maturalny OKE w Jaworznie: Przygotowanie ucznia do egzaminu maturalnego z języka polskiego". Cz. II. Jaworzno 2007.

Kuziak M., Rzepczyński S.: Jak pisać?. Warszawa 2008.

Łuczyński E., Maćkiewicz J.: Językoznawstwo ogólne. Wybrane zagadnienia. Gdańsk 2002.

Maćkiewicz J.: Akapit. W: Eadem: Jak dobrze pisać. Od myśli do tekstu. Warszawa 2010.

Nocoń J.: Rozwijanie i doskonalenie kompetencji tekstotwórczych w pespektywie lingwodydaktycznej. W: „Acta Universitatis Wratislaviensis. Kształcenie Językowe”. Red. K. Bakuła. Wrocław 2012.

Now ak E.: Stworzyć tekst. Uczniowska kompetencja tekstotwórcza w edukacji polonistycznej. Kraków 2014.

Ożóg K.: Polszczyzna przełomu XX i XXI wieku. Wybrane zagadnienia. Rzeszów 2001.

nie podoba. Dlaczego? Uzasadnij swoją opinię, przywołując co najmniej trzy argumenty; Życie bez Internetu było ciekawsze - mówią często dziadkowie. Czy zgadzasz się z tym stwierdzeniem? Uzasadnij swój sąd. Podaj co najmniej trzy argumenty; Do podanych fragmentów opowiadania z dialogiem pt. Strach ma wielkie oczy dopisz brakujący środek. Początek opowiadania: „Było już ciemno. Zmęczeni całodniową wędrówką powoli podchodziliśmy pod mury gotyckiego zamku”. Zakończenie opowiadania: „Dzisiaj śmiejemy się z naszej przygody. Nikomu jednak nie mówimy, że wtedy, tam na dziedzińcu zamku, naprawdę się baliśmy"; Napisz opowiadanie o bardzo radosnym dla Ciebie wydarzeniu. W swojej wypowiedzi wykorzystaj co najmniej pięć związków frazeologicznych spośród podanych: być w czepku urodzonym, być w siódmym niebie, kamień spadt komuś z serca, kuć żelazo póki gorace, mieć głowę na karku, mieć nogi jak z waty, mieć złote serce, nie wierzyć własnym oczom, patrzeć na świat przez różowe okulary, skoczyć po rozum do głowy, skrzydła urosty komuś u ramion, śmiać się od ucha do ucha, śnić na jawie, uwierzyć w siebie, wziq̨é się w garść, z dusza na ramieniu. 
Podstawa programowa z komentarzami. Język polski w szkole podstawowej, gimnazjum i liceum. Warszawa 2008.

Polański E.: Typy uchybień uczniów w organizacji tekstu wypracowań. W: Polonistyka zintegrowana. Red. K. Ożóg, J. Pasterska. Rzeszów 2000.

Rypel A.: Gimnazjaliści w epoce wtórnej oralności. Analiza wybranych wypowiedzi pisemnych. „Polonistyka. Innowacje” 2015, nr 1.

Synowiec H.: Język polski w szkole. W: Polszczyzna 2000. Orędzie o stanie języka na przełomie tysiacleci. Red. W. Pisarek. Kraków 1999.

Synowiec H.: O sytuacji języka ojczystego w zreformowanej szkole. W: Kompetencje nauczyciela polonisty we wspótczesnej szkole. Red. E. Bańkowska, A. Mikołajczuk. Warszawa 2006.

Synowiec H.: Stan polszczyzny uczniów na tle przemian kulturowych i cywilizacyjnych. W: Język polski jako narzędzie komunikacji we wspótczesnym świecie. Red. J. Mazur, M. Rzeszutko-Iwan. Lublin 2007.

Tabisz A.: Kompetencja tekstotwórcza uczniów na przykładzie rozprawki. Opole 2006.

Tymiakin L.: Kompozycja uczniowskiego tekstu argumentacyjnego. „Annales Universitatis Mariae Curie-Skłodowska. Sectio FF, Philologiae”. Vol. XXII. Red. M. Woźniakiewicz-Dziadosz. Lublin 2004.

Wileczek A.: „Zrobić” tekst. O kompetencji tekstotwórczej gimnazjalistów. „Postscriptum Polonistyczne" 2015, nr 2.

Wolańska E.: Kompozycja i spójność wypowiedzi językowej. Strategiczne pozycje tekstowe. W: Praktyczna stylistyka nie tylko dla polonistów. Red. E. Bańkowska, A. Mikołajczuk. Warszawa 2003.

\section{Źródła internetowe}

Skale staninowe. W: Serwis Okręgowej Komisji w Poznaniu. http://uczniowie.oke.poznan.pl. 